\title{
Pembelajaran Statistik Melalui Model Pembelajaran Kooperatif Tipe Snowball Throwing untuk Meningkatkan Hasil Belajar di Kelas VII SMP Negeri 1 Singosari
}

\author{
Dewi Asmarani \\ Fakultas Tarbiyah dan IImu Keguruan, IAIN Tulungagung \\ Jl. Mayor Sujadi Timur No.46 Plosokandang, Tulungagung, Jawa Timur, Indonesia \\ E-mail:dewi asmarani.iainta@yahoo.com
}

\begin{abstract}
Cooperative learning and problem submission is one of the learning models that can be developed and implemented to solving the problem of low activity and learning achievement. One method of cooperative learning can be used to enable students to said their problem is snowball throwing method. This study used a qualitative approach in this case is classroom action research, which consists of two cycles. The result showed that the snowball throwing is proven to help improve learning outcomes of students of class VII-E SMP Negeri 1 Singosari in Statistics. This can be shown on the score of the average value obtained from the initial data, the first cycle and the second cycle (71, 75, and 80) and the thoroughness of classical learning was 83.3\%. Therefore, it is recommended to teachers of mathematics to use Snowball Throwing.
\end{abstract}

Keywords: Statistical Learning, Cooperatif Learning, Snowball Throwing.

\begin{abstract}
Abstrak
Pembelajaran kooperatif dan pengajuan masalah merupakan salah satu model pembelajaran yang dapat dikembangkan dan diterapkan untuk mengatasi masalah rendahnya aktifitas dan prestasi belajar. Salah satu metode dalam pembelajaran kooperatif yang dapat digunakan agar siswa aktif mengajukan masalah adalah metode snowball throwing. Penelitian ini menggunakan pendekatan kualitatif dengan jenis Penelitian Tindakan Kelas (PTK) yang terdiri dari dua siklus. Berdasarkan hasil penelitian diperoleh bahwa pembelajaran kooperatif tipe snowball throwing terbukti dapat membantu meningkatkan hasil belajar siswa kelas VII-E SMP Negeri 1 Singosari pada materi Statistik. Hal ini dapat ditunjukkan dari skor nilai rata-rata yang diperoleh dari data awal, siklus I dan siklus II (71, 75, dan 80) dan ketuntasan belajar klasikal adalah 83,3\%. Untuk itu, disarankan kepada guru matematika dalam pembelajaran matematika khususnya materi Statistik dapat menggunakan model pembelajaran kooperatif tipe Snowball Throwing.
\end{abstract}

Kata Kunci: Pembelajaran Statistik, Model Pembelajaran Kooperatif, Snowball Throwing. 


\section{Pendahuluan}

Matematika merupakan salah satu cabang ilmu pendidikan yang dinilai memberikan kontribusi positif dalam perkembangan pengetahuan dan teknologi. Contohnya aljabar, kalkulus, geometri dan masih banyak lagi. Sementara itu, untuk menguasai ilmu matematika tersebut diperlukan individu-individu yang memiliki kemampuan berpikir tingkat tinggi yang disebut dengan kemampuan berpikir kreatif. Individu seperti inilah yang nantinya diharapkan dapat terus mengawal laju perkembangan pengetahuan dan teknologi. Oleh sebab itu, para guru (maupun calon guru) matematika harus mampu memperbaiki pembelajaran yang terjadi, sehingga penguasaan siswa terhadap matematika dapat lebih baik dan dapat menumbuhkan kemampuan berfikir kreatif siswa.

Pelaksanaan pendidikan di Indonesia lebih menekankan pada pemikiran reproduktif, hafalan dan mencari satu jawaban yang benar terhadap soal-soal yang diberikan. Proses-proses pemikiran seperti berfikir kreatif jarang dilatihkan. Kenyataan ini didukung oleh pendapat Siswono yang mengatakan bahwa perangkat pembelajaran yang menekankan berfikir kreatif dalam matematika tidak tersedia ${ }^{1}$. Buku siswa atau LKS yang ada (digunakan di sekolah) cenderung menekankan pada penguasaan konsep dan memiliki satu jawaban yang benar terhadap soal-soal yang diberikan.

Kondisi seperti di atas, tidak menguntungkan bagi perkembangan dunia pendidikan matematika. Siswa akan mengalami kesulitan penguasaan materi karena pembelajaran dan perangkat pembelajaran yang digunakan sangatlah monoton, sehingga berdampak pada turunnya aktivitas dan prestasi belajar siswa. Perlu terobosan baru dalam pembelajaran untuk menghindari masalah-masalah yang terjadi. Menurut Upu, pendekatan kelompok dan pengajuan masalah dapat dikembangkan dan diterapkan untuk mengatasi masalah rendahnya aktivitas dan prestasi belajar matematika siswa. Lebih lanjut dijelaskan bahwa peningkatan aktivitas belajar matematika siswa dalam pendekatan kelompok dapat dilakukan melalui pertukaran ide atau gagasan 2. Sedangkan pengajuan masalah dapat dilakukan dengan menggunakan model pembelajaran kooperatif tipe snowball throwing, sebab dengan snowball throwing dapat menumbuhkan dan meningkatkan kemampuan berfikir kreatif siswa.

1 Tatag Yuli Eko Siswono, Model Pembelajaran Matematika Berbasis Pengajuan Masalah Dan Pemecahan Masalah Untuk Meningkatkan Kemampuan Berfikir Kreatif (Surabaya: Unesa University Press, 2008).

2 Hamzah Upu, Problem Posing Dan Problem Solving Dalam Pembelajaran Matematika (Bandung: Pustaka Ramadhan, 2003). 


\section{Kerangka Teoretis}

Snowball artinya bola salju, sedangkan Throwing artinya melemparkan. Jadi snowball throwing artinya melemparkan bola salju ${ }^{3}$. Bola salju yang dimaksud disini adalah kertas yang dibentuk seperti bola dan kertas tersebut berisi pertanyaan atau soal yang dibuat oleh masing-masing siswa.

Model pembelajaran kooperatif tipe snowball throwing merupakan salah satu contoh dari metode pembelajaran aktif. Hakekatnya metode pembelajaran aktif untuk mengarahkan perhatian peserta didik terhadap materi yang dipelajari. Pembelajaran aktif adalah proses belajar yang mengajak siswa untuk belajar secara aktif, sehingga peserta didik aktif bertanya dan mengemukakan gagasan ${ }^{4}$. Lebih lanjut menurut Riyanto mengatakan bahwa model pembelajaran kooperatif tipe snowball throwing merupakan salah satu jenis tipe dari pembelajaran kooperatif ${ }^{5}$. Jadi menurut peneliti, snowball throwing merupakan salah satu jenis metode yang dapat digunakan dalam pembelajaran kooperatif untuk mengarahkan atensi peserta didik terhadap materi yang dipelajari dan mengajak siswa untuk belajar secara aktif.

Langkah-langkah model pembelajaran kooperatif tipe snowball throwing adalah sebagai berikut: 6

1. Guru menyampaikan materi yang akan disajikan.

2. Guru membentuk kelompok-kelompok dan memanggil masing-masing ketua kelompok untuk memberikan penjelasan tentang materi.

3. Masing-masing ketua kelompok kembali ke kelompoknya masingmasing, kemudian ketua kelompok menjelaskan materi yang disampaikan oleh guru kepada temannya.

4. Masing-masing siswa diberikan satu lembar kertas kerja, untuk menuliskan satu pertanyaan yang menyangkut materi yang sudah dijelaskan oleh ketua kelompok.

5. Kemudian kertas yang berisi pertanyaan tersebut dibuat seperti bola dan dilempar dari satu siswa ke siswa yang lain selama \pm 15 menit.

3 John M Echols and Hassan Shadily, Kamus Inggris Indonesia: An English. Indonesian Dictionary (Jakarta: PT. Gramedia Pustaka Utama, 2005).

4 Agus Suprijono, Cooperative Learning; Teori Dan Aplikasi PAIKEM (Yogyakarta: Pustaka Pelajar, 2009).

5 Yatim Riyanto, Paradigma Baru Pembelajaran; Sebagai Referensi Bagi Pendidikan Dalam Implementasi Pembelajaran Yang Efektif Dan Berkualitas (Jakarta: Kencana Prenada Media Group, 2009).

${ }^{6}$ Suprijono, Cooperative Learning; Teori Dan Aplikasi PAIKEM; Riyanto, Paradigma Baru Pembelajaran; Sebagai Referensi Bagi Pendidikan Dalam Implementasi Pembelajaran Yang Efektif Dan Berkualitas. 
6. Setelah siswa dapat satu bola atau satu pertanyaan diberikan kesempatan kepada siswa untuk menjawab pertanyaan yang tertulis dalam kertas berbentuk bola tersebut secara bergantian.

7. Evaluasi

8. Penutup

Dalam pembelajaran dengan menggunakan model pembelajaran kooperatif tipe snowball throwing siswa dituntut untuk membuat pertanyaan. Riyanto menyebutkan Pengetahuan seseorang selalu bermulai dari bertanya, bagi siswa membuat pertanyaan merupakan bagian penting dalam melaksanakan pembelajaran yaitu menggali informasi, mengonfirmasikan apa yang sudah diketahui, dan mengarahkan perhatian pada aspek yang belum diketahui ${ }^{7}$.

Menurut Sagala, dalam sebuah pembelajaran, bertanya berguna untuk: (1) Menggali informasi; (2) mengecek pemahaman; (3) membangkitkan respon pada siswa; (4) mengetahui sejauh mana keingin tahuan siswa; (5) mengetahui hal-hal yang sudah diketahui siswa; (6) memfokuskan perhatian siswa pada sesuatu yang dikehendaki guru; (7) untuk membangkitkan lebih banyak lagi pertanyaan dari siswa; (8) untuk menyegarkan kembali pengetahuan siswa. Pada semua aktivitas belajar, bertanya dapat diterapkan antara siswa dengan siswa, antara siswa dengan guru, atau antara siswa dengan orang lain yang didatangkan ke kelas ${ }^{8}$.

\section{Metode Penelitian}

Pendekatan yang digunakan dalam penelitian ini adalah pendekatan kualitatif dan jenisnya adalah Penelitian Tindakan Kelas (PTK). Subyek penelitian dikelas VII E SMPN I Singosari.

Instrumen yang digunakan adalah tes dan lembar observasi. Observasi dilakukan oleh dua orang rekan sejawat yang mengobservasi aktivitas peneliti dan kegiatan siswa. Lembar observasi yang digunakan terbagi menjadi dua yakni lembar observasi guru dan lembar observasi siswa. Intrumen lain yang juga digunakan sebagai sumber data dalam penelitian ini adalah catatan lapangan yang diperoleh selama proses pelaksanaan penelitian. Catatan lapangan memuat kejadian dan fakta di kelas, tempat berlangsungnya penelitian.

Analisis data dalam penelitian ini dilakukan dengan beberapa tahap yaitu: mereduksi data, menyajikan data, dan penarikan kesimpulan. Untuk pengecekan keabsahan datanya dibutuhkan ketekunan Pengamatan, triangulasi, dan pemeriksaan teman sejawat. Kemudian tahap-tahap

7 Riyanto, Paradigma Baru Pembelajaran; Sebagai Referensi Bagi Pendidikan Dalam Implementasi Pembelajaran Yang Efektif Dan Berkualitas.

8 Syaiful Sagala, Konsep Dan Makna Pembelajaran (Bandung: Alfabeta, 2008). 
pelaksanaan penelitiannya terdiri dari, tahap Perencanaan, Pelaksanaan, Pengamatan/observasi, dan Refleksi.

\section{Pembelajaran Statistik melalui Model Pembelajaran Kooperatif tipe Snowball Throwing}

Pembelajaran Statistik melalui model pembelajaran kooperatif tipe snowball throwing dilaksanakan dalam dua pertemuan yang terbagi dalam dua Siklus yaitu Siklus I dan Siklus II. Sebelum pelaksanaan pembelajaran dimulai, peneliti terlebih dahulu membuat rencana pembelajaran sebagai persiapan mengajar dan siswa di kelompokkan pada kelompok-kelompok kecil. Kelompok yang dibentuk terdiri dari siswa yang berkemampuan akademik tinggi, sedang, dan rendah. Hal ini sesuai dengan pendapat Kennedy dan TIPPS bahwa kelompok yang terdiri dari siswa yang berkemampuan tinggi, sedang dan rendah akan dapat memaksimalkan proses belajar karena masing-masing siswa mempunyai kemampuan awal yang berbeda yang pada akhirnya diharapkan prestasi belajar matematika siswa meningkat. Penentuan kelompok dilakukan sebelum pembelajaran berlangsung karena untuk menghemat penggunaan waktu sebelum pembelajaran dimulai ${ }^{9}$.

Pelaksanaan pembelajaran pada Siklus I dengan kompetensi dasar Memahami teknik pengumpulan dan penyajian data dua variabel menggunakan tabel, grafik batang, diagram lingkaran, dan grafik garis dan Siklus II dengan kompetensi dasar Mengumpulkan, mengolah, menginterpretasi, dan menyajikan data hasil pengamatan dalam bentuk tabel, diagram, dan grafik. Model pembelajaran kooperatif tipe snowball throwing dilakukan dengan tiga tahap.

Pada tahap awal, guru menyampaikan tujuan pembelajaran kepada siswa, mengkaitkan dengan kehidupan sehari-hari dan memotivasi siswa dalam belajar. Motivasi belajar sangat berperan penting dalam rangka menyiapkan siswa untuk belajar. Hal ini sesuai dengan pendapat Hudojo bahwa motivasi belajar mendorong peserta didik untuk belajar dengan sungguh-sungguh sehingga pembelajaran lebih bermakna dan dapat dengan mudah mencapai tujuan pembelajaran ${ }^{10}$. Agar tujuan pembelajaran yang telah ditetapkan tercapai maka perlu dilakukan apresepsi mengenai materi Statistik yaitu menentukan sisi, rusuk, titik sudut, diagonal ruang dan bidang

${ }^{9}$ Kholif Lumika, 'Implementasi Pembelajaran Kooperatif Model Two Stay Two Stray (TS- TS) Pada Materi Dimensi Dua Untuk Meningkatkan Prestasi Belajar Matematika Siswa Kelas XI SMK PGRI 02 Malang' (2010). 1990).

10 Herman Hudojo, Strategi Belajar Mengajar Matematika (Malang: IKIP Malang, 
diagonal. Apresepsi bertujuan untuk mengingat kembali materi yang telah dipelajari sebelumnya.

Pada tahap inti, sebelum proses pembelajaran kooperatif tipe snowball throwing berlangsung, guru membagi siswa menjadi beberapa kelompok yang terdiri dari siswa yang heterogen berdasarkan prestasi akademik, sesuai dengan pendapat Nur Asma menyatakan bahwa pengelompokan heterogenitas merupakan ciri-ciri yang menonjol pada model pembelajaran kooperatif 11. Pada kegiatan inti, guru menyampaikan materi yang akan dipelajari, kemudian guru memanggil masing-masing ketua kelompok untuk memberikan penjelasan tentang materi sedangkan siswa yang lain ditugaskan untuk mempelajari materi secara individu. Setelah mendapat penjelasan dari guru masing-masing ketua kelompok kembali ke kelompoknya dan menjelaskan materi yang disampaikan oleh guru kepada temannya. Kemudian guru memberikan Lembar Kerja Kelompok (LKK) yang berisi pertanyaan-pertanyaan yang harus dijawab dalam satu kelompok. Setelah itu, masing-masing siswa diberikan satu lembar kertas kerja, untuk menuliskan satu pertanyaan yang menyangkut materi yang sudah dijelaskan oleh ketua kelompok dan kertas yang berisi pertanyaan tersebut dibuat seperti bola dan dilempar dari siswa ke siswa yang lain. Setelah siswa dapat satu bola atau satu pertanyaan diberikan kesempatan kepada siswa untuk menjawab pertanyaan yang tertulis dalam kertas berbentuk bola tersebut secara bergantian.

Pada akhir pembelajaran, guru memberikan tes kepada siswa untuk mengetahui sejauh mana keberhasilan siswa dalam memahami materi yang dipelajari. Hal ini sesuai dengan pendapat Hudojo menyatakan bahwa pembentukan konsep atau generalisasi perlu diikuti latihan soal agar siswa yakin bahwa setiap konsep yang dipelajari itu benar-benar telah dimengerti sebelum mempelajari konsep atau generalisasi berikutnya 12 .

\section{Hasil Belajar Siswa dengan Menggunakan Model Pembelajaran Kooperatif tipe Snowball Throwing}

Keberhasilan tindakan diukur dengan pencapaian ketuntasan belajar yang disesuaikan dengan Kriteria Ketentusan Minimum (KKM) yang digunakan pada mata pelajaran matematika di SMP Negeri 1 Singosari adalah 70. Adapun ketuntasan secara klasikal yaitu sebesar $75 \%$ siswa mencapai nilai $\geq 70$ dari jumlah siswa. Sebelum penelitian, peneliti menggunakan nilai ulangan harian untuk mengetahui kemampuan awal siswa dan diperoleh

11 Nur Asma, Model Pembelajaran Kooperatif (Jakarta: Departemen Pendidikan Nasional, 2006).

12 Hudojo, Strategi Belajar Mengajar Matematika. 
nilai rata-rata hasil belajar siswa pada ulangan harian adalah 71,94 dan persentase ketuntasan belajar klasikal diperoleh sebanyak 65,63\%.

Tabel 1 Nilai Rata-rata Hasil Belajar Siswa

\begin{tabular}{|l|c|c|c|}
\hline & Prestasi Awal & Siklus I & Siklus II \\
\hline Nilai rata - rata & 71 & 75 & 80 \\
\hline KKM & 70 & 70 & 70 \\
\hline Siswa yang memenuhi KKM & 18 siswa & 21 siswa & 25 siswa \\
\hline Ketuntasan belajar siswa & $60 \%$ & $70 \%$ & $83,3 \%$ \\
\hline
\end{tabular}

Berdasarkan Tabel 1, model pembelajaran kooperatif tipe snowball throwing pada siklus I menunjukkan adanya peningkatan hasil belajar siswa yang diukur dari hasil tesnya. Nilai rata-rata hasil belajar siswa pada tes akhir siklus I adalah 75 dan nilai tersebut adalah rata-rata secara klasikal. Dari hasil belajar individu dapat diketahui bahwa siswa yang tuntas belajar adalah 21 dari seluruh siswa yang memperoleh nilai $\geq 70$ sehingga nilai ketuntasan belajar secara klasikal untuk tes akhir siklus I adalah 70\% dan siswa yang tidak tuntas adalah 30\%. Dari hasil belajar matematika pada siklus I peneliti dapat menyimpulkan bahwa adanya peningkatan hasil belajar siswa. Nilai rata-rata siswa setelah diberikan tindakan meningkat dari 71 menjadi 75. Ketuntasan belajar yang dapat dicapai dengan menggunakan Kriteria Ketuntasan Minimal (KM) yaitu 70 diperoleh sebanyak 70\% siswa atau sebanyak 21 siswa. Hal ini menunjukkan bahawa kreteria keberhasilan penelitian belum tercapai Karena siswa yang mencapai KKM masih kurang dari 75\%. Oleh sebab diputuskan untuk melaksanakan siklus II guna memenuhi ketuntasan belajar yaitu mencapai 75\% dari total keseluruhan siswa.

Pada tes akhir siklus II hasil ketuntasan belajar diperoleh nilai rata-rata hasil belajar siswa adalah 80 dan nilai tersebut adalah rata-rata secara klasikal. Dari hasil belajar individu dapat diketahui bahwa siswa yang tuntas belajar adalah 25 siswa dari seluruh siswa yang memperoleh nilai $\geq 73$ sehingga nilai ketuntasan belajar siswa untuk tes akhir siklus II adalah 83,3\% dan siswa tidak tuntas adalah 16,7\%. Dari data hasil belajar matematika pada siklus II peneliti dapat menyimpulkan bahwa adanya peningkatan hasil belajar siswa karena persentase ketuntasan yang diperoleh berada diatas nilai ketuntasan pada indikator keberhasilan tindakan. Nilai rata-rata siswa setelah diberi tindakan meningkat dari 75 menjadi 80. Ketuntasan belajar yang dapat dicapai dengan menggunakan Kriteria Ketuntasan Minimal (KKM) yaitu 70 diperoleh sebanyak 83,3\% siswa atau sebanyak 25 siswa. Sedangkan ketuntasan belajar klasikal dalam kelas sudah tuntas karena diperoleh sebanyak 25 siswa telah mencapai kriteria yang telah ditentukan. 
Dengan hasil ini diperoleh informasi bahwa model pembelajaran kooperatif tipe snowball throwing berhasil mencapai kriteria yang telah ditetapkan.

\section{Kendala yang Dihadapi dan Solusinya}

Berdasarkan hasil penelitian yang telah dilakukan, terdapat beberapa kendala yang dihadapi diantaranya:

1. Siswa masih kurang aktif pada saat berdiskusi didalam kelompok untuk menyelesaikan Lembar Kerja Kelompok (LKK).

2. Siswa masih malu-malu karena takut ditertawakan oleh temannya dalam menyampaikan hasil diskusi, takut jawabannya salah dan di marahi guru apabila jawabannya salah.

3. Masih ada beberapa siswa yang mengganggu temannya pada saat proses pembelajaran diskusi kelompok yang mengakibatkan konsentrasi temannya jadi terganggu.

Solusi yang diperoleh berdasarkan diskusi dengan guru matematika (sebagai teman sejawat), adalah sebagai berikut

1. Peneliti lebih sering mengingatkan siswa untuk aktif mendiskusikan Lembar Kerja Kelompok (LKK) mereka karena nilai kelompok mereka tergantung dari keaktifan mereka didalam kelompoknya.

2. Peneliti dan teman sejawat mengatur kembali Rencana Pelaksanaan Pembelajaran (RPP) agar tidak menghabiskan waktu yang cukup banyak, dengan pertimbangan bahwa siswa sudah menjalani pembelajaran di siklus I dan di pembelajaran siklus II guru tidak akan selalu susah untuk mengarahkan siswa dalam proses pembelajaran.

3. Peneliti memotivasi siswa untuk tidak takut salah dan memberikan pengarahan, walaupun jawaban mereka salah tidak akan dimarahi oleh peneliti, malah akan dibimbing agar jawabannya benar.

\section{Penutup}

Berdasarkan hasil analisis, diperoleh beberapa kesimpulan sebagai berikut:

1. Penerapan model pembelajaran kooperatif tipe snowball throwing dapat meningkatkan hasil belajar matematika.

2. Deskripsi kegiatan pembelajaran kooperatif tipe snowball throwing pada pokok bahasan Statistik adalah sebagai berikut.

a. Kegiatan Awal

Guru menyampaikan tujuan pembelajaran kepada siswa, mengkaitkan dengan kehidupan sehari-hari dan memotivasi siswa dalam belajar. Motivasi belajar sangat berperan penting dalam rangka menyiapkan siswa untuk belajar. 
b. Kegiatan Inti

Sebelum proses pembelajaran kooperatif tipe snowball throwing berlangsung, guru membagi siswa menjadi beberapa kelompok yang terdiri dari siswa yang heterogen berdasarkan prestasi akademik. Kemudian guru menyampaikan materi yang akan dipelajari, kemudian guru memanggil masing-masing ketua kelompok untuk memberikan penjelasan tentang materi sedangkan siswa yang lain ditugaskan untuk mempelajari materi secara individu. Setelah mendapat penjelasan dari guru masing-masing ketua kelompok kembali ke kelompoknya dan menjelaskan materi yang disampaikan oleh guru kepada temannya. Kemudian guru memberikan Lembar Kerja Kelompok (LKK) yang berisi pertanyaan-pertanyaan yang harus dijawab dalam satu kelompok. Setelah itu, masing-masing siswa diberikan satu lembar kertas kerja, untuk menuliskan satu pertanyaan yang menyangkut materi yang sudah dijelaskan oleh ketua kelompok dan kertas yang berisi pertanyaan tersebut dibuat seperti bola dan dilempar dari siswa ke siswa yang lain. Setelah siswa dapat satu bola atau satu pertanyaan diberikan kesempatan kepada siswa untuk menjawab pertanyaan yang tertulis dalam kertas berbentuk bola tersebut secara bergantian.

c. Kegiatan Akhir

Pada akhir pembelajaran, guru memberikan tes kepada siswa untuk mengetahui sejauh mana keberhasilan siswa dalam memahami materi yang dipelajari.

3. Hasil Belajar

Berdasarkan hasil belajar matematika pada siklus I peneliti dapat menyimpulkan bahwa adanya peningkatan hasil belajar siswa. Nilai ratarata siswa setelah diberikan tindakan meningkat dari 71 menjadi 75 . Ketuntasan belajar yang dapat dicapai dengan menggunakan Kriteria Ketuntasan Minimal (KM) yaitu 70 diperoleh sebanyak 70\% siswa atau sebanyak 21 siswa mencapai KKM sedangkan ketuntasan belajar klasikal dengan minimal 75\% dalam kelas belum tuntas karena masih 70\%. Karena siswa yang mencapai KKM masih kurang dari 75\% maka diputuskan melaksanakan siklus II untuk memenuhi ketuntasan belajar yaitu mencapai 75\% dari total keseluruhan siswa. Berdasarkan data hasil belajar matematika pada siklus II peneliti dapat menyimpulkan bahwa adanya peningkatan hasil belajar siswa karena persentase ketuntasan yang diperoleh berada diatas nilai ketuntasan pada indikator keberhasilan tindakan. Nilai rata-rata siswa setelah diberi tindakan meningkat dari 75 menjadi 80. Ketuntasan belajar yang dapat dicapai dengan menggunakan Kriteria Ketuntasan Minimal (KKM) yaitu 70 
diperoleh sebanyak 83,3\% siswa atau sebanyak 25 siswa telah mencapai KKM sedangkan ketuntasan belajar klasikal dengan minimal 75\% dalam kelas sudah tuntas karena diperoleh sebanyak 25 siswa telah mencapai kriteria yang telah ditentukan. Dengan hasil ini diperoleh informasi bahwa model pembelajaran kooperatif tipe snowball throwing berhasil mencapai kriteria yang telah ditetapkan.

Berdasarkan hasil penelitian, peneliti juga memberikan saran sebagai berikut:

1. Siswa dibiasakan dengan tugas mengajukan masalah, karena pengajuan masalah dapat melatih siswa untuk berfikir kreatif

2. Dalam merencanakan penerapan pembelajaran kooperatif tipe snowball throwing, hendaknya dilakukan perencanaan yang tepat khususnya alokasi waktu, karena dalam membuat pertanyaan siswa membutuhkan waktu yang lama sehingga guru harus memperhitung alokasi waktu dengan baik agar tujuan pembelajaran dapat tercapai

3. Untuk penelitian selanjutnya, dalam membuat RPP dengan menggunakan pembelajaran kooperatif harus menentukan tujuan afektif yang akan dicapai, karena pembelajaran kooperatif selain membelajarkan kecakapan akademik juga membelajarkan keterampilan sosial.

\section{Daftar Pustaka}

Asma, Nur. Model Pembelajaran Kooperatif. Jakarta: Departemen Pendidikan Nasional, 2006.

Echols, John M, and Hassan Shadily. Kamus Inggris Indonesia: An English. Indonesian Dictionary. Jakarta: PT. Gramedia Pustaka Utama, 2005.

Hudojo, Herman. Strategi Belajar Mengajar Matematika. Malang: IKIP Malang, 1990.

Lumika, Kholif. 'Implementasi Pembelajaran Kooperatif Model Two Stay Two Stray (TS- TS) Pada Materi Dimensi Dua Untuk Meningkatkan Prestasi Belajar Matematika Siswa Kelas XI SMK PGRI 02 Malang'. 2010.

Riyanto, Yatim. Paradigma Baru Pembelajaran; Sebagai Referensi Bagi Pendidikan Dalam Implementasi Pembelajaran Yang Efektif Dan Berkualitas. Jakarta: Kencana Prenada Media Group, 2009.

Sagala, Syaiful. Konsep Dan Makna Pembelajaran. Bandung: Alfabeta, 2008.

Siswono, Tatag Yuli Eko. Model Pembelajaran Matematika Berbasis Pengajuan Masalah Dan Pemecahan Masalah Untuk Meningkatkan Kemampuan Berfikir Kreatif. Surabaya: Unesa University Press, 2008.

Suprijono, Agus. Cooperative Learning; Teori Dan Aplikasi PAIKEM. Yogyakarta: Pustaka Pelajar, 2009.

Upu, Hamzah. Problem Posing Dan Problem Solving Dalam Pembelajaran Matematika. Bandung: Pustaka Ramadhan, 2003. 